\title{
Investigation of IAQ in Mechanically Ventilated Kindergartens and Elementary Schools in Korea
}

\author{
Hyeun Jun Moon, Seung Ho Ryu, and Jeong Tai Kim
}

\begin{abstract}
This study investigates the indoor pollutant levels in school buildings according to the operation of mechanical ventilation system. Three classrooms at two different elementary schools and four classrooms at two children's day care center in Korea were chosen for investigation of indoor air quality with mechanical ventilation systems. Measurements were conducted for particulate matter, formaldehyde, total volatile organic compounds, carbon monoxide, carbon dioxide, nitrogen dioxide, ozone, radon, and total bacteria counts. Differences in indoor pollutants concentrations with and without operation of ventilation systems in each classroom were analyzed. The results show that operation of ventilation systems could decrease the levels of indoor pollutants in the classrooms, especially showing the reduction of HCHO concentrations by $14.9-62.3 \%$.
\end{abstract}

Index Terms-Day care centers, elementary schools, indoor air quality, ventilation system.

\section{INTRODUCTION}

Indoor air quality is an increasing public health concern due to the amount of time spent indoors. (70-90\%) [1]. Poor indoor air quality can cause many adverse health effects such as respiratory symptoms and asthma [2], [3]. School children spend about $6-8 \mathrm{~h}$ per weekday in classrooms, which is the second most time-spent indoor environment after homes [4]. Moreover children are more susceptible to indoor pollutants, including airborne particles, volatile organic compounds since their organs are in developing stage and they breathe more air relative to their body size than adults [5], [6]. Thus, good indoor air quality should be maintained in schools for children's health. Several studies have reported that the indoor air problems can increase the chance of long-term and short-term health problems for students and teachers in terms of comfort and productivity [7], [8].

Several studies have been conducted during the past decades to investigate the indoor air quality in school buildings such as children's day care center and elementary schools. Roda et al. [9] have investigated the indoor environment in 28 Paris child day care centers. They reported that the child day care centers indoor/outdoor ratio for most chemical pollutants was above unity except for $\mathrm{NO}_{2}$, the levels for $\mathrm{NO}_{2}$ being significantly higher than those measured in homes. Zuraimi and Tham [10] have investigated indoor pollutants concentrations in child care centers and evaluated their determinants involving

Manuscript received June 22, 2014; revised July 23, 2014. This work was supported by the National Research Foundation of Korea (NRF) grant funded by the Korea government (MSIP) (No. 2008-0061908).

The authors are with the Department of Architectural Engineering, Dankook University, Yongin-si 448-701, Republic of Korea (e-mail: hmoon@dankook.ac.kr, lemon415@dankook.ac.kr, jtkim@khu.ac.kr). representative samples in Singapore. This study reported that indoor $\mathrm{CO}_{2}$ concentration levels were lower in Singapore child care centers when compared to child care centers from other cold climate countries due to the higher ventilation rate of child care centers in Singapore. St-Jean et al. [11] have assessed indoor air quality in 21 day care centers in Montréal, Canada and determined association between building characteristics and IAQ. They reported that over $85 \%$ of the day care centers had a mean $\mathrm{CO}_{2}$ concentration higher than $1000 \mathrm{ppm}$. The mean formaldehyde concentration was $22.9 \mu \mathrm{g} / \mathrm{m}^{3}$. They also reported that the presence of a mechanical ventilation system and a large surface of play are per child were significantly associated with lower $\mathrm{CO}_{2}$ levels. Chitra and Nagendra [4] have investigated indoor air quality parameters in a naturally ventilated school building located near an urban roadway in India. This study reported that the mean value of indoor $\mathrm{PM}_{10}$, $\mathrm{PM}_{2.5}, \mathrm{PM}_{1}$ and $\mathrm{CO}$ concentrations were found to be $149 \pm 69$, $61 \pm 29,43 \pm 24,0.10 \pm 0.18$ and $95 \pm 61,32 \pm 16,18 \pm 9$ $\mu \mathrm{g} / \mathrm{m}^{3}, 0.11 \pm 0.14 \mathrm{ppm}$, respectively for winter and summer seasons. Norback et al. [12] have studied the relationship between VOCs, respirable dust, and personal factors to prevalence and incidence of sick building syndrome in six primary schools. They reported that the average $\mathrm{CO}_{2}$ concentrations in all sites were greater than $800 \mathrm{ppm}$ and indicated inadequate ventilation. Lee and Chang [13] investigated IAQ of five classrooms in Hong Kong. This study showed that the average respirable suspended particulate matter (RSPM) concentrations were higher than the Hong Kong air quality objective (annual average, $55 \mu \mathrm{g} / \mathrm{m}^{3}$ ) and the maximum indoor $\mathrm{PM}_{10}$ level exceeded $1000 \mu \mathrm{g} / \mathrm{m}^{3}$. Yang et al. [14] characterized the concentrations of different indoor air pollutants within Korean schools and to compare their indoor levels within schools according to the age of school buildings. The I/O ratio for $\mathrm{HCHO}$ was 6.32 during the autumn, and the indoor $\mathrm{HCHO}$ concentrations (mean $=0.16 \mathrm{ppm}$ ) in schools constructed within 1 year were significantly higher than the Korean Indoor Air Standard, indicating that schools have indoor sources of HCHO. FROMME et al. [15] evaluated indoor air quality in 64 schools in the city of Munich and a neighboring district outside the city boundary. They reported that the median indoor $\mathrm{CO}_{2}$ concentration in a classroom was $1603 \mathrm{ppm}$ in winter and $405 \mathrm{ppm}$ in summer. Median $\mathrm{PM}_{2.5}$ concentrations of $19.8 \mu \mathrm{g} / \mathrm{m}^{3}$ and $\mathrm{PM}_{10}$ concentrations of 91.5 $\mu \mathrm{g} / \mathrm{m}^{3}$ were observed during winter period. In summer, a reduced PM concentrations were reported (median $\mathrm{PM}_{2.5}=12.7$ $\mu \mathrm{g} / \mathrm{m}^{3}$, median $\mathrm{PM}_{10}=64.9 \mu \mathrm{g} / \mathrm{m}^{3}$ ).

One of the strategies to maintain good indoor air quality in buildings is to use mechanical ventilation systems. Adequate ventilation systems should not only provide thermal comfort but also distribute fresh air to occupants and remove 
pollutants. This study aims to investigate the indoor pollutant levels in school classrooms according to the operation of mechanical ventilation system. Differences in indoor pollutants concentrations with and without operation of mechanical ventilation systems in each classroom are analyzed. Investigation of indoor air quality in classrooms helps us to characterize pollutant levels and effects of ventilation systems.

\section{METHODS}

\section{A. Field Measurements Design}

A field study was conducted in seven classrooms at two different kindergartens and two elementary schools located in Korea. Detailed description of the selected day care centers and elementary schools is shown in Table I. Mechanical ventilation systems were installed in all selected classrooms, as shown Fig. 1. The measurements were taken in two different ventilation operation modes (before and after operation of ventilation system), with the aim of investing the effect of ventilation system on the indoor air pollutants concentrations.

TABLE I: DESCRIPTION OF THE SELECTED SCHOOL BUILDINGS AND ClASSROOMS

\begin{tabular}{llll}
\multicolumn{3}{c}{ CLASSROOMS } \\
\hline \hline \multicolumn{2}{l}{ Target buildings } & Selected classrooms & Construction years \\
Day care & DCC-A & 2 (DCC-A1, DCC-A2) & 11 years \\
center & DCC-B & 2(DCC-B1, DCC-B2) & 3 years \\
Elementary & ES-A & 1 (ES-A1) & 7 years \\
school & ES-B & 2(ES-B1, ES-B2) & 2 years \\
\hline \hline
\end{tabular}
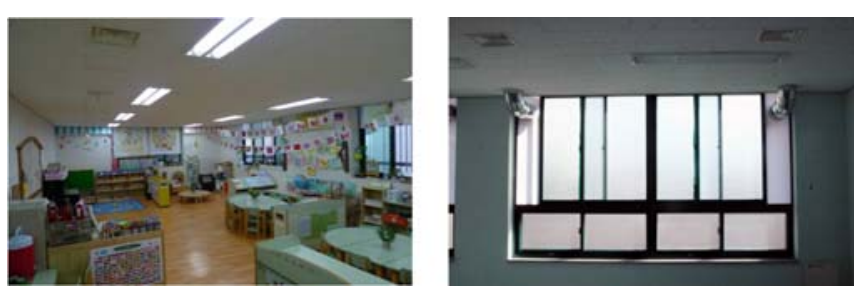

Fig. 1. Ventilation systems in selected classrooms.

\section{B. Measurement of the Indoor air Pollutants}

One-day indoor air quality investigations at each school were performed. The indoor pollutants were monitored for particle matter $\left(\mathrm{PM}_{10}\right)$, Carbon monoxide $(\mathrm{CO})$, Carbon dioxide $\left(\mathrm{CO}_{2}\right)$, Nitrogen dioxide $\left(\mathrm{NO}_{2}\right)$, Ozone $\left(\mathrm{O}_{3}\right)$, Radon $(\mathrm{Rn})$, total bacteria count, Formaldehyde (HCHO) and Volatile Organic Compounds (VOCs). Indoor air temperature and relative humidity were also monitored during the field measurement. Samplings were performed in the middle of classroom near the breathing zone of children.

Measurement methods for each indoor pollutant were referred to the Indoor air quality control in public use facilities, an act provided by the Ministry of Environment, Korea [16]. $\mathrm{PM}_{10}$ samples were collected on a pall flex membrane filter using mini volume air sampler. $\mathrm{CO}$ and $\mathrm{CO}_{2}$ were measured by means of a non-dispersive infrared (NDIR) analyzer (CO Analyzer 300E and CD 98 Plus). $\mathrm{NO}_{2}$ was measured by means of a chemiluminescence analyzer $\left(\mathrm{NO}_{2}\right.$ Analyzer 200E). $\mathrm{O}_{3}$ was measured by means of an ultraviolet photometric analyzer $\left(\mathrm{O}_{3}\right.$ Analyzer 400E). Radon was measured based on continuous radon monitoring method using the RAD7. The sampling method employed for the total bacteria count was a MAS impactor, which used the centrifugal impaction principle. HCHO was collected by pulling air through a 2,4-DNPH cartridge (MP- $\left.\sum 100\right)$. The DNPH-HCHO derivative eluted with acetonitrile was determined by a reverse-phase high-performance liquid chromatography (HPLC). TVOCs' samples were collected using Tenax-TA tubes, which were analyzed by gas chromatography with flame ionization detection and a modified thermal desorption cold trap injector.

\section{RESUlTS AND DisCUSSIONS}

\section{A. Indoor Air Quality in the Selected Elementary Schools According to Ventilation Mode}

A field study in elementary school was conducted in three class rooms (ES-A1, ES-B1 and ES-B2) at two different elementary schools (ES-A and ES-B). Indoor air pollutants levels in ES-A1 were monitored while the classroom was unoccupied. The measurements were conducted before and after the operation of ventilation system while an air-conditioner system was not operated. Table II shows the level of indoor air pollutants measured at ES-A1 according to operation of mechanical ventilation system.

TABLE II: CONCENTRATIONS OF INDOOR AIR POLLUTANTS MEASURED IN ES-A1

\begin{tabular}{llll}
\hline \hline Pollutants & Standard $^{*}$ & $\begin{array}{l}\text { Before the } \\
\text { operation of vent. }\end{array}$ & $\begin{array}{l}\text { After the } \\
\text { operation of vent. } \\
\mathrm{T}\left({ }^{\circ} \mathrm{C}\right)\end{array}$ \\
$\mathrm{RH}(\%)$ & - & 23.2 & 22.5 \\
$\mathrm{PM}_{10}\left(\mu \mathrm{g} / \mathrm{m}^{3}\right)$ & 100 & 34.5 & 31.1 \\
$\mathrm{CO}(\mathrm{ppm})$ & 10 & 33.3 & 16.7 \\
$\mathrm{CO}_{2}(\mathrm{ppm})$ & 1000 & 0.03 & 0.03 \\
$\mathrm{NO}_{2}(\mathrm{ppb})$ & 50 & 519 & 467 \\
$\mathrm{O}_{3}(\mathrm{ppb})$ & 60 & 26.5 & 23.7 \\
$\mathrm{Rn}(\mathrm{pCi} / \mathrm{l})$ & 4.0 & N.D. & N.D. \\
$\mathrm{TBC}\left(\mathrm{CFU} / \mathrm{m}^{3}\right)$ & 800 & 0.5 & 0.3 \\
$\mathrm{HCHO}\left(\mu \mathrm{g} / \mathrm{m}^{3}\right)$ & 100 & 150 & 40 \\
$\mathrm{TVOC}\left(\mu \mathrm{g} / \mathrm{m}^{3}\right)$ & 400 & 52.8 & 19.9 \\
\hline \hline
\end{tabular}

${ }^{*}$ Korean Indoor Air Standard [16]

** Not detected

Indoor air pollutants levels in ES-B1 and ES-B2 were monitored while the classrooms were unoccupied. The measurements in ES-B1 and ES-B2 were conducted before and after the operation of ventilation system while air-conditioner systems were turned on. In case of the elementary school B, measurement of the indoor pollutants were focused on particle matter $\left(\mathrm{PM}_{10}\right)$, carbon dioxide $\left(\mathrm{CO}_{2}\right)$, formaldehyde (HCHO) and volatile organic compounds (VOCs) excluding other pollutants since other pollutants were measured significantly lower from pre-test. Table III-IV show the level of indoor air pollutants measured at elementary school B according to operation of mechanical ventilation system.

\section{B. Indoor Air Quality in the Selected Day Care Centers According to Ventilation Mode}

A field study in day care center was conducted in four class rooms (DCC-A1, DCC-A2, DCC-B1 and DCC-B2) at two different day care centers (DCC-A and DCC-B). In case of 
day care centers, measurements of the indoor pollutants were focused on particle matter $\left(\mathrm{PM}_{10}\right)$, carbon monoxide $(\mathrm{CO})$, carbon dioxide $\left(\mathrm{CO}_{2}\right)$, formaldehyde $(\mathrm{HCHO})$ and volatile Organic Compounds (VOCs). Table V-VIII show the level of indoor air pollutants measured at each day care center according to operation of mechanical ventilation system.

TABLE III: CONCENTRATIONS OF INDOOR AIR POLLUTANTS MEASURED IN ES-B1

\begin{tabular}{llll}
\hline \hline & & Before the & After the \\
Pollutants & Standard $^{*}$ & $\begin{array}{l}\text { operation of vent. } \\
\text { operation of vent. }\end{array}$ & 21.8 \\
$\mathrm{~T}\left({ }^{\circ} \mathrm{C}\right)$ & - & 21.7 & 26.3 \\
$\mathrm{RH}(\%)$ & - & 30.9 & 65.2 \\
$\mathrm{PM}_{10}\left(\mu \mathrm{g} / \mathrm{m}^{3}\right)$ & 100 & 75.7 & 350 \\
$\mathrm{CO}_{2}(\mathrm{ppm})$ & 1000 & 470 & 34.0 \\
$\mathrm{HCHO}\left(\mu \mathrm{g} / \mathrm{m}^{3}\right)$ & 100 & 43.0 & 205.5 \\
$\mathrm{TVOC}\left(\mu \mathrm{g} / \mathrm{m}^{3}\right)$ & 400 & 360.0 & \\
\hline \hline
\end{tabular}

TABLE IV: CONCENTRATIONS OF INDOOR AIR POLLUTANTS MEASURED IN

\begin{tabular}{llll}
\multicolumn{3}{c}{ ES-B2 } \\
\hline \hline Pollutants & Standard $^{*}$ & Before the & After the \\
& & operation of vent. & operation of vent. \\
$\mathrm{T}\left({ }^{\circ} \mathrm{C}\right)$ & - & 23.2 & 22.3 \\
$\mathrm{RH}(\%)$ & - & 24.1 & 15.7 \\
$\mathrm{PM}_{10}\left(\mu \mathrm{g} / \mathrm{m}^{3}\right)$ & 100 & 87.5 & 25.0 \\
$\mathrm{CO}_{2}(\mathrm{ppm})$ & 1000 & 510 & 360 \\
$\mathrm{HCHO}\left(\mu \mathrm{g} / \mathrm{m}^{3}\right)$ & 100 & 32.7 & 27.7 \\
$\mathrm{TVOC}\left(\mu \mathrm{g} / \mathrm{m}^{3}\right)$ & 400 & 259.4 & 191.3 \\
\hline
\end{tabular}

TABLE V: CONCENTRATIONS OF INDOOR AIR POLLUTANTS MEASURED IN

\begin{tabular}{llll}
\multicolumn{3}{c}{ DCC-A1 } \\
\hline \hline \multirow{3}{*}{ Pollutants } & Standard* & $\begin{array}{l}\text { Before the } \\
\text { operation of vent. }\end{array}$ & $\begin{array}{l}\text { After the } \\
\text { operation of vent. } \\
\end{array}$ \\
$\mathrm{PM}_{10}\left(\mu \mathrm{g} / \mathrm{m}^{3}\right)$ & 100 & 104.2 & 71.5 \\
$\mathrm{CO}(\mathrm{ppm})$ & 10 & 0.23 & 0.06 \\
$\mathrm{CO}(\mathrm{ppm})$ & 1000 & 437 & 934 \\
$\mathrm{HCHO}\left(\mu \mathrm{g} / \mathrm{m}^{3}\right)$ & 100 & 75.1 & 63.9 \\
$\mathrm{TVOC}\left(\mu \mathrm{g} / \mathrm{m}^{3}\right)$ & 400 & 379.4 & 66.2 \\
\hline \hline
\end{tabular}

TABLE VI: CONCENTRATIONS OF INDOOR AIR POLLUTANTS MEASURED IN

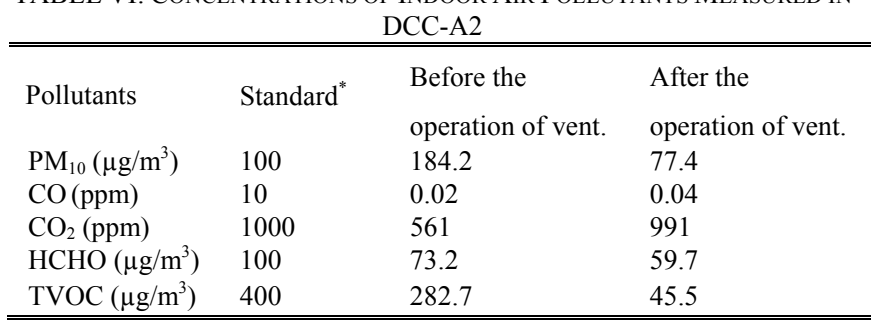

TABLE VII: CONCENTRATIONS OF INDOOR AIR POLLUTANTS MEASURED IN DCC-B1

\begin{tabular}{|c|c|c|c|}
\hline Pollutants & Standard* & Before the & After the \\
\hline PM $\left(\mu / m^{3}\right)$ & 100 & operation of vent. & operation of vent \\
\hline $\mathrm{CO}(\mathrm{ppm})$ & 10 & 0.66 & 0.02 \\
\hline $\mathrm{CO}_{2}(\mathrm{ppm})$ & 1000 & 643 & 623 \\
\hline $\operatorname{HCHO}\left(\mu \mathrm{g} / \mathrm{m}^{3}\right)$ & 100 & 60.1 & 26.6 \\
\hline TVOC $\left(\mu \mathrm{g} / \mathrm{m}^{3}\right)$ & 400 & 348 & 31.1 \\
\hline
\end{tabular}

\section{Indoor Air Pollutants Levels by Operation of the Mechanical Ventilation System}

The indoor $\mathrm{PM}_{10}$ concentrations in the elementary school A, elementary school B, day care center A and day care center $\mathrm{B}$, on average, decreased by $49.8,42.6,44.7$ and
$23.2 \%$, respectively by operation of the mechanical ventilation systems. The mean of decreasing rates of indoor $\mathrm{CO}_{2}$ concentrations were $10.0,27.5$ and $26.8 \%$ in the elementary school A, elementary school B and day care center $\mathrm{B}$, respectively. In contrast, $\mathrm{CO}_{2}$ concentrations in the day care center $\mathrm{A}$ increased by $95.2 \%$. It is assumed that because of the change in number of children and increase of outdoor $\mathrm{CO}_{2}$ concentration (from 277 to $435 \mathrm{ppm}$ ) during the filed measurements. The mean of decreasing rates of indoor HCHO concentrations were $62.3,18.1,16.7$ and $58.2 \%$ in the elementary school A, elementary school B, day care center A and day care center $\mathrm{B}$, respectively. The indoor TVOC concentrations in the elementary school A, elementary school $\mathrm{B}$, day care center $\mathrm{A}$ and day care center $\mathrm{B}$, on average, decreased by $46.5,34.6,83.2$ and $82.1 \%$, respectively.

Our results clearly showed that indoor air pollutants' level after operation of the ventilation system were lower than before operation of the ventilation system expect in the case of $\mathrm{CO}_{2}$ concentrations at the day care center A. These results could be explained by the adequate ventilation by means of a mechanical ventilation system. Fig. 2 shows the TVOC concentration changes in classrooms according to operation of the mechanical ventilation system.

TABLE VIII: CONCENTRATIONS OF INDOOR AIR POLLUTANTS MEASURED IN DCC-B2

\begin{tabular}{|c|c|c|c|}
\hline Pollutants & Standard* & Before the & After the \\
\hline & & operation of vent. & operation of vent. \\
\hline $\mathrm{PM}_{10}\left(\mu \mathrm{g} / \mathrm{m}^{3}\right)$ & 100 & 86.7 & 64.7 \\
\hline $\mathrm{CO}(\mathrm{ppm})$ & 10 & 0.64 & 0.01 \\
\hline $\mathrm{CO}_{2}(\mathrm{ppm})$ & 1000 & 1013 & 502 \\
\hline $\mathrm{HCHO}\left(\mu \mathrm{g} / \mathrm{m}^{3}\right)$ & 100 & 58.6 & 23.1 \\
\hline TVOC $\left(\mu \mathrm{g} / \mathrm{m}^{3}\right)$ & 400 & 170.2 & 45.6 \\
\hline
\end{tabular}

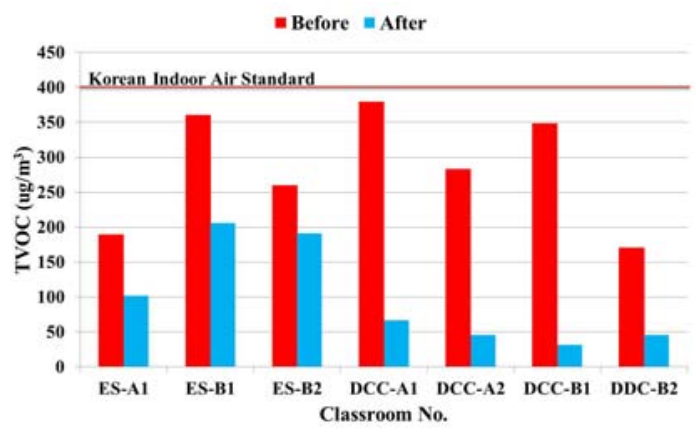

Fig. 2. TVOC concentrations in classrooms according to operation of the mechanical ventilation system.

Zuraimi and Tham [17] have documented the relation between indoor pollutant levels and child day care center ventilation mode such as naturally ventilated, hybrid ventilated and air conditioning with or without mechanical ventilation. They found that the level in hybrid ventilation systems lower than other systems by means of increased dilution of pollutants. Smedje and Norback [18] have conducted a study in Swedish schools and found that schools in which a new ventilation system was installed had higher exchange rates and reduced exposure to several pollutants including $\mathrm{CO}_{2}$, $\mathrm{HCHO}$ and VOCs.

There were slight differences between the decreasing rates of each school buildings. An explanation might be the difference of outdoor pollutants concentrations at the 
boundary with each school buildings, efficiencies of the mechanical ventilation system, number of occupants, operation of air-conditioners and location of diffusers.

The indoor air concentrations of all measured pollutants after operation of ventilation system in the selected school buildings complied with the Korean Indoor Air Standard, although measurements were conducted for one-day only. The mean of the $\mathrm{PM}_{10}$ concentrations were 16.7, 45.1, 74.5 and $65.1 \mu \mathrm{g} / \mathrm{m}^{3}$ in the ES-A, ES-B, DCC-A and DCC-B, respectively. The mean of the $\mathrm{CO}_{2}$ concentrations were 467, 355, 963 and $563 \mathrm{ppm}$ in the ES-A, ES-B, DCC-A and DCC-B, respectively. The mean of the $\mathrm{HCHO}$ concentrations were $19.9,30.9,61.8$ and $24.9 \mu \mathrm{g} / \mathrm{m}^{3}$ in the ES-A, ES-B, DCC-A and DCC-B, respectively. The mean of the TVOC concentrations were $101.4,198.4,55.9$ and $38.4 \mu \mathrm{g} / \mathrm{m}^{3}$ in the ES-A, ES-B, DCC-A and DCC-B, respectively.

\section{CONCLUSION}

In this study, we analyzed the indoor air quality parameters in four different school buildings with mechanical ventilation system to characterize pollutant levels and effects of ventilation systems. The results had shown remarkable difference in indoor air pollutants' level according to the operation of mechanical ventilation system. Operation of ventilation systems could decrease the levels of indoor pollutants in most of the selected classrooms, especially showing the reduction of chemical pollutants, $\mathrm{HCHO}$ and TVOC concentrations by 35.5 and $65.5 \%$, respectively. Therefore, adequate ventilation by means of a mechanical ventilation system can play key roles in improving the indoor air quality within school buildings.

\section{REFERENCES}

[1] N. E. Klepeis, W. C. Nelson, W. R. Ott, J. P. Robinson, A. M. Tsang, P. Switzer, J. V. Behar, S. C. Hern, and W. H. Engelmann, "The national human activity pattern survey (NHAPS): a resource for assessing exposure to environmental pollutants," Journal of Exposure Analysis and Environmental Epidemiology, vol. 11, pp. 231-252, 2001.

[2] Y. H. Mi, D. Norback, J. Tao, Y. L. Mi, and M. Ferm, "Current asthma and respiratory symptoms among pupils in Shanghai, China: influence of building ventilation, nitrogen dioxide, ozone, and formaldehyde in classrooms," Indoor Air, vol. 16, pp. 454-464, 2006.

[3] E. Johanning, P. Landsbergis, M. Gereis, C. S. Yang, and E. Olmsted, "Clinical experience and results of a sentinel health investigation related to indoor fungal exposure," Environmental Health Perspectives, vol. 107, pp. 489-494, 1999.

[4] V. S. Chithra and S. Nagendra, "Indoor air quality investigations in a naturally ventilated school building located close to an urban roadway in Chennai, India," Building and Environment, vol. 54, pp. 159-167, 2012.

[5] E. M. Faustman, S. M. Silbernagel, R. A. Fenske, T. M. Burbacher, and R. A. Ponce, "Mechanisms underlying children's susceptibility to environmental toxicants," Environmental Health Perspectives, vol. 108 , pp. 13-21, 2000.

[6] J. M. Mendell and G. A. Health, "Do indoor pollutants and thermal conditions in schools influence student performance? A critical review of the literature," Indoor Air, vol. 15, pp. 27-52, 2005.

[7] F. V. Dijken, J. V. Bronswijk, and J. Sundell, "Indoor environment in Dutch primary schools and health of the pupils," in Proc. indoor air 2005, pp. 623-627, Beijing, 2005.

[8] P. Wargocki, D. P. Wyon, B. Matysiak, and S. Irgens, "The effects of classroom air temperature and outdoor air supply rate on the performance of school work by children," in Proc. indoor air 2005, pp. 368-372, Beijing, 2005.

[9] C. Roda, S. Barra, H. Ravelomanantsoa, M. Dusseaux, M. Tribout, Y. L. Moullec, and I. Momas, "Assessment of indoor environment in Paris child day care centers," Environmental Research, vol. 111, pp. 1010-1017, 2011.

[10] M. S. Zuraimi and K. W. Tham, "Indoor air quality and its determinants in tropical child care centers," Atmospheric Environment, vol. 42, pp. 2225-2239, 2008.

[11] M. S. Jean, A. S. Amand, N. L. Gilbert, J. C. Soto, M. Guay, K. Davis, and T. W. Gyorkos, "Indoor air quality in Montreal area day-care centres, Canada," Environmental Research, vol. 118, pp. 1-7, 2012.

[12] D. Norback, M. Torgen, and C. Edling, "Volatile organic compounds, respirable dust and personal factors related to prevalence and incidence of sick building syndrome in primary schools," British Journal of Industrial Medicine, vol. 47, pp. 733-741, 1990.

[13] S. C. Lee and M. Chang, "Indoor and outdoor air quality investigation at schools in Hong Kong," Chemosphere, vol. 41, pp. 109-113, 2000.

[14] W. H. Yang, J. R. Shon, J. H. Kim, B. S. Son, and J. C. Park, "Indoor air quality investigation according to age of the school buildings in Korea," Journal of Environmental Management, vol. 90, pp. 348-354, 2009.

[15] H. Fromme, D. Twardella, S. Dietrich, D. Heitmann, R. Schierl, and B. Liebl, "Particulate matter in the indoor air of classrooms-exploratory results from Munich and surrounding area," Atmospheric Environment, vol. 41, pp. 854-886, 2007.

[16] Indoor Air Quality Control in Public Use Facilities, etc. Act, Korea ministry of Environment, Act No. 10789-2011.

[17] M. S. Zuraimi and K. W. Tham, "Effects of child care center ventilation strategies on volatile organic compounds of indoor and outdoor origins," International Journal of Environmental Science and Technology, vol. 42, pp. 2054-2059, 2008.

[18] G. Smedje and D. Norback, "New ventilation systems at select schools in Sweden-effects on asthma and exposure," Archives of Environmental Health: An International Journal, vol. 55, pp. 18-25, 2000.

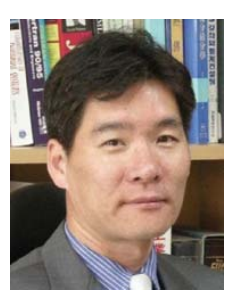

Hyeun Jun Moon received Ph.D. degree in building technology from the Georgia Institute of Technology, USA. His Ph.D. work focused on the development a probabilistic performance indicator for mould growth risk under uncertainty. $\mathrm{He}$ is now an associate professor at Department of Architectural Engineering of Dankook University, Korea. He worked as a research fellowship in the Building Technology Center in Oak Ridge National Laboratory, USA before joining Dankook University. His research interests include building energy simulation and optimization, building information modeling, building mould and Indoor air quality.

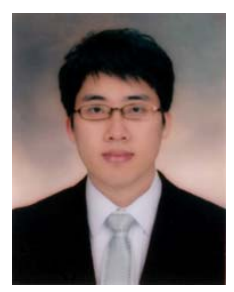

Seung Ho Ryu received M.S. degree in architectural engineering from the Dankook University in 2011. His M.S. thesis was "Analysis of energy efficiency and hygrothermal performance in buildings". He is now Ph.D. candidate and research associate at Department of Architectural Engineering of Dankook University, Korea.

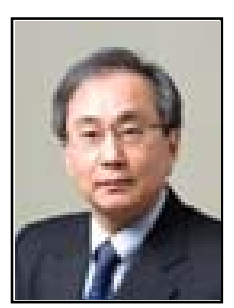

Jeong Tai Kim is a Kyung Hee distinguished fellow at Kyung Hee University and is a fellow of the Korea Academy of Science and Technology (KAST). In September of 2008, He founded the center for sustainable healthy buildings $(\mathrm{CSHeB})$ with the award of engineering research center (ERC) from Korea Government. As the director of the $\mathrm{CSHeB}$, he has tried to establish an outstanding R\&D center with global competitiveness by providing on-site research facilities, formulating synergistic interconnection with interdisciplinary researchers, and promoting collaboration and cooperation with various industries, government departments, and international universities. He also plays a key role in promoting sustainable healthy building technologies academically by hosting international symposiums, seminars, and workshops. He acted as the president of the Acoustical Society of Korea (2005), the Korea Institute of Ecological Architecture and Environment (2007-2008), and currently acts as the president of the Korea Society of Lighting and Visual Environment and the vice-president of the International Society of the Built Environment. 